\title{
HBV DNA ve HCV RNA'sı Pozitif Olan Kronik Hepatit B ve C Hastalarında Otoantikor Seroprevalansının Araştırılmasıi
}

\author{
The Investigation of Autoantibody Seroprevalence In HBV DNA and \\ HCV RNA Positive Chronic Hepatitis B and C Patients
}

${ }^{2}$ Konya Meram Tip Fakültesi Hastanesi Tibbi Mikrobiyoloji KKahramnmaraş Sütçü imam Üniversitesi Tıp Fakültesi Tibbi Mikrobiyoloji Anabilim Dalı 4 Kahramanmaraş Sütçü İmam Üniversitesi, Sağllk Hizmetleri Meslek Yüksekokulus

Yazışma Adresi / Correspondence:

\section{Seda Acar}

Kahramanmaraş Sütçü İmam Üniversitesi Sağlık Bilimleri Enstitüsü Tıbbi Mikrobiyoloji

P: +90505 7382932

E-mail: seda.acar.1991@hotmail.com

Geliş Tarihi / Received : 26.05.2017

Kabul Tarihi / Accepted : 02.06.2017

\section{Özet}

Amaç Bu çalımada HBV DNA ve HCV RNA'sı pozitif olan hastalarda, Anti-nükleer antikor (ANA), Anti-Double Stranded DNA (dsDNA), Anti-single stranded DNA (ssDNA), Anti-SM Antikor, Anti-tiroglobulin Antikor(a-TG), Anti-düz kas antikor(ASMA), Anti-mitokondriyal antikor M2(AMA-M2), Karaciğer böbrek mikrozomal antikor-1 (LKM-1) otoantikorlarının seroprevelansını saptamak ve değerlerin kendi aralaıında ve normal populasyon değerleriyle karşılaşıııılması planlanmıştır.

Gereç ve Yöntemler: 30 HBV DNA'sı pozitif, 30 HCV RNA 'sı pozitif Kronik hepatit B ve C tanılı hasta serumları ve 30 sağıklı kontrol grubu serum örnekleri kullanılarak yapılmıştır.Çalıșma sırasında serumlar oda sıcaklığında eritilmesinin ardından ELiSA yöntemi ile çalışılmıştır.

Bulgular: $\quad$ Hepatit B hasta grubunda 3 olguda ANA(\%10), 10 olguda ASMA (\%33.3), 1 olguda LKM-1(\%3.3), 16 olguda AMA-M2(\%53.3), 1 olguda anti-TG(\%3.3), 3 olguda anti-ds DNA(\%10), 3 olguda anti-ss DNA(\%10) antikor pozitifliği olmak üzere 20 HBV-DNA pozitif hastada toplam 37 otoantikor varlı̆ı belirlenmiştir. Kronik hapatit C grubunda, 4 olguda ANA (\%13.3), 14 olguda ASMA (46.7), 2 olguda LKM-1(\%6.7), 12 olguda AMA-M2 (\%40), 5 olguda anti-TG(\%16.7), 4 olguda anti-ds DNA (\%13.3), 4 olguda anti-ss DNA (\%13.3) antikor pozitifliği olmak üzere $23 \mathrm{HCV}$-RNA pozitif hastada toplam 45 otoantikor varlığı belirlenmiştir. Kontrol grubunda ise 2 olguda ANA (\%6.7), 5 olguda ASMA(\%16.7), 8 olguda AMA-M2(\%26.7), 3 olguda anti-TG(\%10), 2 olguda anti-ds DNA (\%6.7), 2 olguda anti-ss DNA (\%6.7), antikor pozitifliği olmak üzere 14 sağlıklı hastada toplam 22 otoantikor varlığı belirlenmiştir.

Sonuç: Kronik hepatit B ve C'de yapılan bu çalışmada HBV ve HCV'nin otoantikor oluşumunu uyardığı̆ görülmüștür. ( Sakarya Tıp Dergisi J 2017, 7(2):79-84 )

Anahtar Kelimeler: $\quad$ HBV, HCV, Otoimmünite, Otoantikor

\section{Abstract}

Objective: The purpose of this study is to determine the sero-prevalence of anti-nuclearantibody (ANA), anti-straight muscle antibody (ASMA), liver kidney micro-chromosomal antibody1(LKM-1), anti-mitochondrial antibody M2 (AMA-M2), anti-thyro-globulin antibody (a-TG), anti-double stranded DNA (dsDNA), anti-single stranded DNA (ssDNA) and anti-SM antibodies in patients with chronic hepatitis B and C who were diagnosed with chronic hepatitis B and hepatitis C and had positive HBV DNA and HCV RNA, and compare these values between themselves and values obtained normal population.

Material and Methods: $\quad 30$ HBV DNA and 30 HCV RNA positive Chronic hepatitis B and C and 30 healthy control group serum samples. During the study, serums were melted at room temperature and then worked by ELISA method.

Results: Hepatitis B patients; 3 involved ANA (10 \%), 10 ASMA (33,3 \%), 1 LKM-1 (3,3\%), 16 AMA-M2 (53,3 \%), 1 anti-TG (3,3 \%), 3 anti-dsDNA (10 \%), and 3 anti- ssDNA (10 \%) Hepatitis C; 4 involved ANA (13,3 \%), 14 ASMA (46,7 \%), 2 LKM-1 (6,7 \%), 12 AMA-M2 (40 \%), 5 anti-TG (16,7 \%), 4 antidsDNA (13,3\%), and 4 anti-ssDNA (13,3 \%).In a group of 14 healthy patients; 2 involved ANA (6,7 \%), 5 ASMA (16,7 \%), 8 AMA-M2 (26,7 \%), 3 anti-TG (10 \%), 2 anti-dsDNA (6,7 \%), and 2 anti-ssDNA (6,7 \%).

Conclusion: This study of chronic hepatitis B and C showed that HBV and HCV induced autoantibody formation. ( Sakarya Med J 2017,7(2):79-84 ).

Keywords: HBV, HCV, Autoımmunity, Auto-Antibodies 


\section{Giriş}

Organizmanın kendi doku antijenlerine karşı immün cevap oluşturmasına bağlı olarak gelişen otoimmün hastalıklarda vücudun kendi proteinlerine karşı otoantikor oluşturduğu bilinmektedir. ${ }^{1}$ Otoimmünite ve otoimmün hastalıkların gelişmesinde, viral enfeksiyonların bazı mekanizmalar aracilığ ile rolü olduğu bilinmektedir. $^{2}$ Hepatit $B$ virüsü (HBV) ve hepatit $C$ virüsü (HCV) dünya çapında önemli viral enfeksiyonlar olup akut ya da kronik hepatit, karaciğer sirozu ve hepatosellüler kansere (HCC) sebep olabilirler. Çeşitli çalışmalar HBV ve HCV'nin otoimmün romatolojik hastaIıkların oluşum mekanizmalarını tetiklediği ve her iki durumda da dolaşımdaki immünkomplekslerin depolanmasında artış olduğunu bildirmişlerdir. ${ }^{3}$ HCV'nün otoimmün olaylarla ilişkisinin daha güçlü olduğu bilinmekle birlikte, HBV de immün tolerans kaybına yol açarak otoimmün olayları artırabilir veya yeni otoimmün olaylara neden olabilir. ${ }^{4}$ Bu virüslerin ekstrahepatik lezyonlarının patogenezi, immünolojik mekanizmalar aracilığıla indirekt veya sitopatik etkisi ile direkt olarak kabul edilebilir. ${ }^{5}$

\section{MATERYAL VE METOT}

Bu çalışma Kahramanmaraş Sütçü İmam Üniversitesi Sağılı Uygulama ve Araştırma Hastanesinde çeşitli kliniklere başvuran $30 \mathrm{HBV}$ DNA'sı pozitif, 30 HCV RNA'sı pozitif Kronik hepatit B ve C tanısı almış hasta serumları ve 30 sağlıklı kontrol grubu serum örnekleri kullanılarak yapılmıştır. En az 6 ay süreyle HBsAg, HBV-DNA, anti-HCV, HCV-RNA pozitifliği ve kronik Hepatit $\mathrm{B}, \mathrm{C}$ tanısı almış hastalar çalışmaya alındı. Tüm hasta serum örnekleri $-80^{\circ} \mathrm{C}$ 'de derin dondurucuda saklanmıştır. Çalışma sırasında serumlar oda sıcaklığında eritilmesinin ardından ELiSA yöntemi ile çalışılmıştır.

Anti-nükleer antikor (ANA), Anti-Double Stranded DNA (dsDNA), Anti-single stranded DNA (ssDNA), Anti-SM Antikor, Anti-tiroglobulin Antikor(a-TG), Anti-düz kas antikor(ASMA), Anti-mitokondriyal antikor M2(AMA-M2), Karaciğer böbrek mikrozomal antikor-1 (LKM-1) antikor düzeyleri belirlenmiştir. i̇statistiksel analiz için SPSS 15.0 programı kullanılmıştır. Analizlerde ayrıca Pearson -Chi Square testi ve Fisher's Exact testi kullanılmıştır. Analiz sonucunda $p<0.05$ değeri anlamlı kabul edilmiştir.

\section{Bulgular}

30 HBV DNA'sı pozitif kronik hepatit B hasta grubunda; 3 olguda (\%10) ANA pozitifliği, 10 olguda $(\% 33,3)$ ASMA pozitifliği, 1 olguda $(\% 3,3)$ LKM-1 antikor pozitifliği, 16 olguda $(\% 53,3)$ AMA-M2 pozitifliği, 1 olguda (\% 3,3) anti-TG antikor pozitifliği, 3 olguda (\%10) anti-dsDNA ve anti- ssDNA antikor pozitifliği saptanmıștır. Olguların hiç birinde anti-SM antikor pozitifliği saptanmamıștır. (Tablo 1)

\begin{tabular}{|l|c|c|c|}
\hline \multicolumn{4}{|c|}{ Tablo 1. Kronik hepatit B hasta grubunda otoantikor varlığı } \\
\hline OTOANTiKOR & Pozitif Sayı $(\%)$ & Negatif Sayı $(\%)$ & Toplam Sayı $(\%)$ \\
\hline ANA & $3(\% 10)$ & $27(\% 90)$ & $30(\% 100)$ \\
\hline ASMA & $10(\% 33.3)$ & $20(\% 66,7)$ & $30(\% 100)$ \\
\hline LKM-1 & $1(\% 3.3)$ & $29(\% 96,7)$ & $30(\% 100)$ \\
\hline AMA-M2 & $16(\% 53.3)$ & $14(\% 46,7)$ & $30(\% 100)$ \\
\hline ANTi-TG & $1(\% 3.3)$ & $29(\% 96,7)$ & $30(\% 100)$ \\
\hline ANTi-DS DNA & $3(\% 10)$ & $27(\% 90)$ & $30(\% 100)$ \\
\hline ANTI SS-DNA & $3(\% 10)$ & $27(\% 90)$ & $30(\% 100)$ \\
\hline ANTi SM & $0(\% 0)$ & $30(\% 100)$ & $30(\% 100)$ \\
\hline TOPLAM & $37(\% 13.7)$ & $233(\% 86,3)$ & $270(\% 100)$ \\
\hline Anti) &
\end{tabular}

Anti-nükleer antikor (ANA), Anti-Double Stranded DNA (dsDNA),

Anti-single stranded DNA (ssDNA), Anti-SM Antikor, Anti-tiroglobulin Antikor (a-TG), Anti-düz kas antikor (ASMA), Anti-mitokondriyal antikor M2(AMA-M2), Karaciğer böbrek mikrozomal antikor-1 (LKM-1).

30 HCV RNA'sı pozitif kronik hepatit $C$ hasta grubunda; 4 olguda $(\% 13,3)$ ANA pozitifliği, 14 olguda ( $\% 46,7)$ ASMA pozitifliği, 12 olguda (\%6,7 ) LKM-1 antikor pozitifliği, 12 olguda (\%40 ) AMA-M2 pozitifliği, 5 olguda (\%16,7 ) anti-TG pozitifliği, 4 olguda $(\% 13,3)$ anti-dsDNA ve anti-ssDNA antikor pozitifliği saptanmıştır. Olguların hiç birinde Anti-SM antikor pozitifliği saptanmamıştır. (Tablo 2)

30 sağlıklı kontrol grubunda; 2 olguda $(\% 6,7)$ ANA pozitifliği, 5 olguda ( \%16,7) ASMA pozitifliği, 8 olguda $(\% 26,7)$ AMA-M2 pozitifliği, 3 olguda (\%10) anti-TG pozitifliği, 2 olguda $(\% 6,7)$ antidsDNA pozitifliği, 2 olguda (\%6,7 ) anti-ssDNA antikor pozitifliğ saptanmıştır. Olguların hiç birinde Anti-SM ve LKM-1 antikor pozitifliği saptanmamıştır. (Tablo 3 )

Kronik hepatit B hasta grubunda; 3 olguda (\%10) ANA pozitifliği, 10 olguda $(\% 33,3)$ ASMA pozitifliği, 1 olguda $(\% 3,3)$ LKM-1 an- 
tikor pozitifliği, 16 olguda $(\% 53,3)$ AMA-M2 pozitifliği, 1 olguda $(\% 3,3)$ anti-TG antikor pozitifliği, 3 olguda $(\% 10)$ anti-dsDNA ve anti- ssDNA antikor pozitifliği saptanmıştır.Olguların hiç birinde anti-SM antikor pozitifliği saptanmamıştır. Kronik hepatit $\mathrm{C}$ hasta grubunda; 4 olguda $(\% 13,3)$ ANA pozitifliği, 14 olguda $(\% 46,7)$ ASMA pozitifliği, 2 olguda $(\% 6,7)$ LKM-1 antikor pozitifliği, 12 olguda (\%40 ) AMA-M2 pozitifliği, 5 olguda $(\% 16,7)$ anti-TG pozitifliği, 4 olguda $(\% 13,3)$ anti-dsDNA ve anti-ssDNA antikor pozitifliği saptanmıştır. Olguların hiç birinde anti-SM antikor pozitiflliği saptanmamıştır. İstatistiksel açıdan karşılaştırıldığında otoantikor pozitifliği bakımından kronik hepatit $\mathrm{B}$ ve kronik hepatit $\mathrm{C}$ grupları arasında anlamlı farklılık izlenmemiştir(p>0.05). (Tablo 4)

\begin{tabular}{|l|c|c|c|}
\hline \multicolumn{4}{|l|}{ Tablo 2. Kronik hepatit C hasta grubunda otoantikor varlığı } \\
\hline OTOANTiKOR & Pozitif Sayı (\%) & Negatif Sayı (\%) & Toplam Sayı (\%) \\
\hline ANA & $4(\% 13,3)$ & $26(\% 86,7)$ & $30(\% 100)$ \\
\hline ASMA & $14(\% 46,7)$ & $16(\% 53,3)$ & $30(\% 100)$ \\
\hline LKM-1 & $2(\% 6,7)$ & $28(\% 93,3)$ & $30(\% 100)$ \\
\hline AMA-M2 & $12(\% 40)$ & $17(\% 60)$ & $30(\% 100)$ \\
\hline ANTi-TG & $5(\% 16,7)$ & $25(\% 83,3)$ & $30(\% 100)$ \\
\hline ANTi-DS DNA & $4(\% 13,3)$ & $26(\% 86,7$ & $30(\% 100)$ \\
\hline ANTi-SS DNA & $4(\% 13,3)$ & $26(\% 86,7)$ & $30(\% 100)$ \\
\hline ANTi SM & $0(\% 0)$ & $30(\% 100)$ & $30(\% 100$ \\
\hline TOPLAM & $45(\% 16,6)$ & $225(\% 83,4)$ & $270(\% 100)$ \\
\hline $\begin{array}{l}\text { Anti-nükleer antikor (ANA), Anti-Double Stranded DNA (dsDNA), Anti-single } \\
\text { stranded DNA (ssDNA), Anti-SM Antikor, Anti-tiroglobulin Antikor(a-TG), Anti-düz } \\
\text { kas antikor(ASMA), Anti-mitokondriyal antikor M2(AMA-M2), Karaciğer böbrek } \\
\text { mikrozomal antikor-1 (LKM-1). }\end{array}$ \\
\hline
\end{tabular}

\begin{tabular}{|l|c|c|c|}
\hline \multicolumn{5}{|l|}{ Tablo 3. Sağlıklı kontrol grubunda otoantikor varlığı } \\
\hline OTOANTiKOR & Pozitif Sayı (\%) & Negatif Sayı (\%) & Toplam Sayı (\%) \\
\hline ANA & $2(\% 6,7)$ & $28(\% 86,7)$ & $30(\% 100)$ \\
\hline ASMA & $5(\% 16,7)$ & $25(\% 53,3)$ & $30(\% 100)$ \\
\hline LKM-1 & $0(\% 0)$ & $30(\% 93,3)$ & $30(\% 100)$ \\
\hline AMA-M2 & $8(\% 26,7)$ & $22(\% 56,7$ & $30(\% 100)$ \\
\hline ANTi-TG & $3(\% 10)$ & $27(\% 83,3)$ & $30(\% 100)$ \\
\hline ANTi-DS DNA & $2(\% 6,7)$ & $28(\% 86,7)$ & $30(\% 100)$ \\
\hline ANTi-SS DNA & $2(\% 6,7)$ & $28(\% 86,7)$ & $30(\% 100)$ \\
\hline ANTTi & $0(\% 0)$ & $30(\% 100$ & $30(\% 100)$ \\
\hline TOPLAM & $22(\% 8,1)$ & $248(\% 91,9)$ & $270(\% 100)$ \\
\hline $\begin{array}{l}\text { Anti-nükleer antikor (ANA), Anti-Double Stranded DNA (dsDNA), Anti-single } \\
\text { stranded DNA (ssDNA), Anti-SM Antikor, Anti-tiroglobulin Antikor(a-TG), Anti-düz } \\
\text { kas antikor(ASMA), Anti-mitokondriyal antikor M2(AMA-M2), Karaciğer böbrek } \\
\text { mikrozomal antikor-1 (LKM-1). }\end{array}$ \\
\hline
\end{tabular}

\begin{tabular}{|c|c|c|c|c|}
\hline \multicolumn{5}{|c|}{$\begin{array}{l}\text { Tablo 4. Kronik hepatit B ile Kronik hepatit C hasta gruplarında } \\
\text { otoantikorların dağılımı }\end{array}$} \\
\hline Otoantikor & $\begin{array}{l}\text { Kronik } \\
\text { Hepatit } \\
\text { B } \cap(\%)\end{array}$ & $\begin{array}{c}\text { Kronik } \\
\text { Hepatit C } \\
\text { n (\%) }\end{array}$ & $x^{2}$ değeri & +p değer \\
\hline ANA & $3(\% 10)$ & $4(\% 13,3)$ & 0.496 & 0.481 \\
\hline ASMA & $10(\% 33,3)$ & $14(\% 46,7)$ & 0.065 & 0.799 \\
\hline LKM-1 & $1(\% 3,3)$ & $2(\% 6,7)$ & 0.071 & 0.789 \\
\hline AMA-M2 & $16(\% 53,3)$ & $12(\% 40)$ & 0.675 & 0.411 \\
\hline Anti-TG & $1(\% 3,3)$ & $5(\% 16,7)$ & 0.200 & 0.655 \\
\hline Anti-dsDNA & $3(\% 10)$ & $4(\% 13,3)$ & 0.496 & 0.481 \\
\hline Anti-ssDNA & $3(\% 10)$ & $4(\% 13,3)$ & 0.496 & 0.481 \\
\hline Anti-SM & $0(\% 0)$ & $0(\% 0)$ & $-* *$ & $-{ }^{* *}$ \\
\hline \multicolumn{5}{|c|}{$\begin{array}{l}\text { Anti-nükleer antikor (ANA), Anti-Double Stranded DNA (dsDNA), Anti-single } \\
\text { stranded DNA (ssDNA), Anti-SM Antikor, Anti-tiroglobulin Antikor(a-TG), Anti-düz } \\
\text { kas antikor(ASMA), Anti-mitokondriyal antikor M2(AMA-M2), Karaciğer böbrek } \\
\text { mikrozomal antikor-1 (LKM-1). } \\
\text { n: pozitif say } \\
\text { +: Chi-Square Testi } \\
\text {-**. }\end{array}$} \\
\hline
\end{tabular}

\section{Tartışma}

Otoreaktivite karaciğer hastalıklarında sıklıkla karşımıza çıkmakta özellikle ilaçlara, kimyasal maddelere ve enfeksiyonlara bağlı olarak meydana gelmektedir. Enfeksiyonlar içinde ise HCV en sık etken olarak görülmektedir. Virüsün indüklediği otoimmünitenin mekanizma teorileri 3 kategoride incelenmektedir. Bunlar otoantijen değisimi, konakçı immün yanıt bozukluğunun otoantikor üretim kontrolündeki bozukluğa neden olması ve moleküler taklitçilik (mimicry) olarak sayllabilir. ${ }^{6}$ HBV ve HCV'de klinik öneme sahip karaciğer dışı hastalıkların sıklı̆ı yüksek olabilmektedir. ${ }^{7} \mathrm{Bu}$ nedenle HBV ve HCV bulaşlarında karaciğer dışı hastalıkların bulgusu olan otoantikorların dikkatle değerlendirilmesi gerekmektedir. Yapılan birçok çalışmada hepatit B ve hepatit C 'li bireylerde farklı oranlarda otoantikor varlığı bildirilmiştir. Bu çalışmada ise HBV DNA ve HCV RNA'sı pozitif olan kronik hepatit B ve C tanısı alan hastalar ve kontrol grubu bireylerde: Anti-nükleer antikor (ANA), anti-düz kas antikor (ASMA), karaciğer böbrek mikrozomal antikor-1(LKM-1), antimitokondriyal antikor M2 (AMA-M2), anti troglobulin antikor (anti-TG), anti-çift sarmal DNA (dsDNA), anti- tek sarmal DNA (ssDNA), anti SM antikorlarının serumda pozitifliği araştııılmıştır.

Anti-nükleer antikor (ANA) pozitifliği çalışmamızda, kronik hepatit B hasta grubunda bulunan 30 olgunun 3'ünde (\%10), kronik 
hepatit C hasta grubunda bulunan 30 olgunun 4'ünde $(\% 13,3)$, kontrol grubunda 30 olgunun 2'sinde $(\% 6,7)$ pozitif tespit edilmiştir. Gruplar arasında ANA pozitifliği yönünden istatistiksel olarak anlamlı bir fark bulunmamıştır ( $p>0.05$ ). Czaja ve arkadaşları tarafından 20 HBV, 75 HCV bulaşına bağlı kronik viral hepatitli 95 hastada yapılan çalışmada; HBV'de 4(\%20) olguda HCV'de 40(\%53) olguda ANA pozitifliği bulunmuş olup HBV ve HCV grupları arasında istatistiksel olarak anlamlı bir fark bulunmuştur. ${ }^{8}$ Gregoria ve arkadaşlarının çocuklardan oluşan 65 HBV, 24 HCV'li hasta ve 24 kontrol grubunu içeren çalışmada; HBV grubunda 21 olguda (\%32), HCV grubunda ise 4 olguda (\%16) ANA pozitifliği bulunurken, kontrol grubunda hiç bir olguda pozitiflik bulunmamıştır. ${ }^{9}$ Lenzi ve arkadaşlarının yaptıkları çalışmada; 87 HBV, 226 HCV'li hasta ile 226 kontrol grubunda ANA incelenmiş HBV grubunda 2 olguda (\%2,3), HCV grubunda 36 olguda (\%16) pozitif bulunurken, kontrol grubunda 8 olguda $(\%$ 3,5) pozitif bulunmuştur. Bu çalışmada ANA pozitifliği açısından hasta ve kontrol grupları arasında anlamlı bir fark bulunmuştur. ${ }^{10}$

Anti-düz kas antikor (ASMA) kronik otoimmün aktif hepatitli hastalarda \%70-90 pozitiflikte bulunurken, \%12 sıklıkla da sağlıklı bireylerde pozitif bulunabilir. Çalışmamızda ASMA varlığı, kronik hepatit B hasta grubunda bulunan 30 olgunun 10'unda $(\% 33,3)$, kronik hepatit $\mathrm{C}$ hasta grubunda bulunan 30 olgunun 14 'ünde ( $\%$ $46,7)$, kontrol grubunda ise 30 olgunun 5 'inde $(\% 16,7)$ pozitif saptanmıștır. Kronik hepatit B ile kronik hepatit $\mathrm{C}$ hasta grubu, kronik hepatit B hasta grubu ile kontrol grubu, kronik hepatit $\mathrm{C}$ hasta grubu ile kontrol grubu arasında ASMA pozitifliği yönünden istatistiksel olarak anlamlı bir fark saptanmamıştır(p>0.05). Gregoria ve arkadașları çocuklardan oluşan, $65 \mathrm{HBV}, 24 \mathrm{HCV}$ ve 24 kontrol grubunu içeren bir çalışmasında; HBV grubundaki 23 (\%35) olguda, HCV grubunda $8(\% 33,3)$ olguda, kontrol grubundaki olgularda ise hiç bir olguda ASMA pozitifliği bulunmamıştı̊ . Bu çalışmada hasta grubundaki sonuçlar birbirine oranla yakın bulunmuş olup, bizim çalışmamızda ise HCV ve kontrol gruplarında ASMA pozitifliği daha yüksek HBV grubunda ise bu çalışma ile yakın oranda bulunmuștur'. Czaja ve arkadaşları tarafından 20 HBV, 75 HCV'ne bağlı kronik viral hepatitli 95 hastada, HBV bulaşında 2(\%10) HCV bulaşında 10(\%13,3) olguda ASMA pozitifliği bulunmuştur. Aynı araştıııcının yaptığı diğer bir çalışmada 16 HBV bulaşına bağlı 2 olguda $(\% 12,5)$ ASMA pozitif bulunmuştur. ${ }^{11}$

Karaciğer böbrek mikrozomal antikor-1 (LKM-1) pozitifliği çaIışmamızda, kronik hepatit B hasta grubunda 1(\%3,3), kronik hepatit C hasta grubunda $2(\% 6,7)$ olguda pozitif bulunmuş, kontrol grubundaki olguların hiç birinde pozitiflik bulunamamıştır. Gruplar arasında ise LKM-1 antikoru pozitifliği yönünden istatistiksel olarak anlamlı bir fark saptanmamıştır( $p>0.05)$. Li ve arkadaşlarının Çin'de 360 kronik hepatit C, 69 kronik hepatit B, 59 Otoimmün hepatitli hasta gruplarında gerçekleştirdikleri çalışmada; LKM1antikoru HCV'li hasta grubunda 9(\%3), HBV'li hasta grubunda $0(\% 0)$, otoimmün hepatitli hasta grubunda ise $2(\% 3)$ oranında pozitif bildirmişlerdir. ${ }^{12}$ Koşar ve arkadaşlarının ülkemizde yapıtıkları çalışmada; HBV ve HCV'ne bağlı kronik karaciğer hastalığında LKM-1 otoantikoru hiç bir olguda pozitif bulunmamıştır.Literatürdeki benzer çalışmalarda HBV bulaşına bağlı olgularda LKM-1 negatif bulunmuştur(8). Drygiannakis ve arkadaşları tarafından kronik hepatit $\mathrm{C}$ tanısı almış 142 hasta ve kontrol grubu olarak 60 adet sağlıklı donör gruplarında gerçekleştirdikleri çalışmada LKM-1 antikor pozitifliğini hasta grubunda $1(\% 0,7)$, kontrol grubunda ise hiçbir olguda pozitiflik bildirmemişlerdir. ${ }^{13}$

Çalışmamızda Antimitokondriyal antikor M2 (AMA-M2) pozitifliği, kronik hepatit B hasta grubunda 16(\%53,3) olguda, kronik hepatit C hasta grubunda $12(\% 40)$ olguda, kontrol grubunda $8(\% 26,7)$ olguda pozitifllik saptanmıştır. Gruplar arasında AMA-M2 pozitifliği yönünden istatistiksel olarak anlamlı bir fark saptanmamıştır( $p>0.05)$. Çalışmamızda hasta gruplarındaki AMA-M2 pozitiflik oranımı literatürde ${ }^{9,14}$ bildirilenlere oranlara yüksek bulunmuş olup HBV ve HCV'nin bu otoantikorun oluşumundan sorumlu bir faktör olabileceğini düşündürmektedir. Kronik HCV hastalarında ise, Pawlotsky ve ark. ${ }^{15}$ ile Rostaing ve ark. ${ }^{16}$, AMA-M2 pozitifliğini hiç bir hastada tespit edememişken, Grimbert ve ark. ${ }^{17} \% 1.5$, Barrett ve ark. ${ }^{18}$ \%3.8, Ersöz ve ark. ${ }^{19} \% 9$, Yumuk ve ark. ${ }^{20} \% 3.1$ oranında pozitiflik bildirmişlerdir.

Kronik $\mathrm{B}$ ve $\mathrm{C}$ hepatitinde İnterferon tedavisi ile ilişkili olarak tiroid fonksiyon bozukluğu ve otoimmün tiroid hastalıklarının birlikteliğini bildiren çalışmalar vardır. ${ }^{21}$ Bizim çalışmamızda ise; tiroid otoantikoru olan anti-TG antikorunun kronik hepatit $B$ ve $C$ hasta ve 
kontrol grubu serum örneklerinde araştırdık. Çalışma sonucunda kronik hepatit B hasta grubunda $1(\% 3,3)$ olguda, kronik hepatit C hasta grubunda $5(\% 16,7)$ olguda, kontrol grubunda $3(\% 10)$ olguda pozitif bulunmuştur. Gruplar arasında anti-TG antikoru pozitifliği yönünden istatistiksel olarak anlamlı bir fark saptanmamıştır( p>0.05).Okanoue ve arkadaşları interferon tedavisi alan 494 kronik hepatit $\mathrm{C}$ hastasının sekizinde hipertiroidi, üçünde ise hipotiroidi meydana geldiğini rapor etmişlerdir. ${ }^{22}$

Hepatit B ve C virüsü ile otoimmün romatizmal hastalık arasındaki ilişkiyi incelemek için, sistemik otoimmün hastalıkların (artrit, SLE) tanısında kullanılan anti-DNA( anti-dsDNA, anti-ssDNA) antikorları ve anti-SM antikorlarını kronik hepatit $B$ ve $C$ hasta ve kontrol grubu serum örneklerinde pozitifliğini araştırdık. Anti-dsDNA ve antissDNA antikorları, kronik hepatit B hasta grubunda 3(\%10), kronik hepatit $\mathrm{C}$ hasta grubunda $4(\% 13,3)$, kontrol grubunda $2(\% 6,7)$ olguda pozitif bulunmuştur. Anti-SM antikoru ise; kronik hepatit B, kronik hepatit $C$ hasta gruplarında ve kontrol grubundaki olguların hiç birinde pozitif saptanmamıştır. Gruplar arasında otoantikor pozitifliği yönünden anti-dsDNA, anti-ssDNA ve anti-SM antikor pozitifliği yönünden istatistiksel olarak anlamlı bir fark bulunamamıştı. Ülkemizde Beşirbelioğlu ve ark. ${ }^{23}$, kronik HCV hastalarında, Seçkin ve ark. ${ }^{24}$ kronik HBV ve HCV hastalarında yaptıkları çalışmada anti-ds-DNA hiç tespit edemediklerini bildirmişlerdir.

Bu çalışmada; HBV ve HCV' ne bağlı kronik viral hepatitlerde otoimmünite ve otoimmün hastalıklar için özgün olan ANA, LKM-1, AMA-M2, anti-TG, anti-dsDNA, anti-ssDNA, antikor pozitifliğinin sıklğı açısından normal populasyona oranla daha fazla pozitif bulunmuş olmakla beraber; hasta gruplarıyla kontrol grubu arasında antikor pozitifliğinin sıklğı açısından bir fark görülmeyip, ASMA pozitifliği yönünden ise istatistiksel olarak anlamlı bir fark bulunmamıştır. Kronik hepatit B ve C'de otoantikorların sıklı̆ını araştıran tüm çalışmalarda HBV ve HCV'nin otoantikor oluşumunu başlattığı görülmüş ve farkı sonuçlar elde edilmiştir.

Bu çalışmada, daha duyarlı ancak daha az özgül olan ELISA yöntemi kullanılmışır. Otoantikor pozitifliğinin belirlenmesinde tek bir yöntemle tanıya gidilmesinin gerçekçi bir uygulama olmadığını düşünmekteyiz. Otoantikor test yöntemlerinde ELISA yönteminin yanında en yaygın kullanılan ve altın standart olan IFA yöntemi ile beraber kullanılması, daha güvenilir ve sağlıklı sonuçlara ulaşılması açısından gerekli bir uygulama olacağını düşünmekteyiz. 


$84 \begin{array}{ll}\text { Sakarya Tip Dergisi } \\ 2017 ; 7(2): 79-84\end{array} \quad \begin{aligned} & \text { ACAR ve Ark. } \\ & \text { HBV DNA ve HCV RNA'sı Pozitif Olan Kronik Hepatit B ve C Hastalarında Otoantikor Seroprevalansının Araştırılması }\end{aligned}$

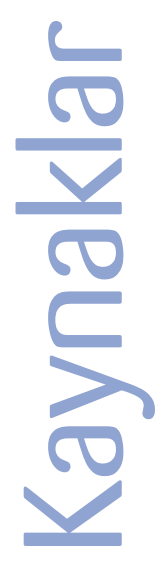

1. Ian R, Mackay M.D, Fred S, Rosen M.D. Autoimmun diseases. New England Journal of Medicine. 2001; 345(5): 340-350.

2. Horwitz MS, Sarvetnick N. Virüses, Host responses, and Autoimmunity. Immunology Reviews. 1999; 169: 241-253.

3. Strassburg CP, Manss MP. Interferon and autoimmunity: implications for managing side effects. In: Dianzani F, Valtuena JP, eds. Lymphoblastoid alpha-interferon. London: Butler\&Tanner Ltd, 1995: 238-247.

4. Hsu TC, Tsay GJ, Chen TY, et al. Anti-PCNA autoantibodies preferentially recognize C-terminal of PCNA in patients with chronic hepatitis B virus infection. Clin Exp Immunol 2006; 144: 110-116.

5. Uzunalimoğlu Ö. Viral hepatitlerde ekstrahepatik manifestasyonlar. Viral Hepatit 2001, Kılıçturgay K, Badur S (eds) Viral Hepatitle Savasım Derneği Yayını, 2001: 297-302.

6. Shantha S, Thyagarajan SP, Premavathy RK, Sukumar RG, Mohan KV, Palanisamy KR, et al. Correlation of autoimmune reactivity with hepatitis $B$ and $C$ virus ( $\mathrm{HBV}$ and $\mathrm{HCV}$ ) infection in histologically proven chronic liver diseases. Indian J Med Microbiol 2002; 20: 12-15.

7. Pyrsopoulos NT, Reddy K: Extrahepatic manifestations of choronic viral hepatitis.Curr Gastroenterol Rep 2001; 3: 71-78.

8. Czaja AJ, Carpenter HA, Sandranch PJ, Moore SB immunologic features and HLA associations in chronic viral hepatitis. Gastroenterology1995; 108: 157-164.

9. Gregorio GV, Choudhuri K, Ma Y, Vegnente A, Mieli-Vergani G, Vergani D.Mimicry between the hepatitis B virus DNA polymerase and the antigenic targets of nuclear and smooth muscle antibodies in chronic hepatitis B virus infection. J Immunol 1999; 162: 1802-1810.

10. Lenzi M, Bellentani S, Saccocio G, Masutti F, Muratori L, Cassani $F$ et al: Prevalence of non-organ-specific autoantibodies and chronic liver disease in the general population: A nested casecontrol study of the Dionysos cohort. Gut 1999;45: 435- 444

11. Czaja AJ, Carpenter HA, Santrach PJ, Moore B:Genetic predispositions for the immunological features of chronic active hepatitis. Hepatologyl 1993; (18)4: 816-822.

12. Li B, Zhen-Ru F, Hai-Ying L, Wen-gang L, Min Y, Xiao-Yuan X.Prevalence ofantinuclear and anti-liver-kidney-microsome type- 1 antibodies in patients with chronic hepatitis $C$ in China: Chinese Medical Journal 2009; 122(1): 5-9.

13. Drygiannakis D, Lionis C, Drygiannakis I, Pappas G, and Kouroumalis E.Low prevalence of liver-kidney microsomal autoantibodies of type 1 (LKM1) in hepatitis C seropositive subjects on Crete, Greece. BMC Gastroenterology 2001; 1: 4.

14. Czaja AJ. Performance Parameters of the Conventional Serological Markers for Autoimmune Hepatitis. Dig Dis Sci (2011) 56: 545-554.

15. Pawlotsky JM, Yahia BM, Andre C, Voisin MC, et al. Immunolgicai disorders in $\mathrm{C}$ virus chronic active hepatitis: a prospective case-control study. Hepatology 1994; 19: 842-847.

16. Rostaing L, Modesto A, Cisterne JM, et al. Serological markers of autoimmunity in renal transplant patients with chronic hepatitis C. Am J Nephrol 1998; 18: 50-56.

17. Grimbert S, Johanet C, Bendjaballah F, Homberg JC, Poupon R, Beaugrand M. Antimitocondrial antibodies in patients with chronic hepatitis C. Liver 1996; 16:161-165.

18. Barrett S, Goh J, Coughlan B et al. The natural course of hepatitis $C$ virus infection after 22 years in a unique homogenous cohort: spontaneous viral clearance and chronic HCV infection.
Gut 2001; 49: 423-430.

19. Ersöz G, Akarca US, Topalak Ö, Batur Y, Yılmaz F, Başdemir G, Erensoy S. Kronik viral hepatitlerde oto antikorlar. T Klin J Gastroenterohepatol 1997; 8: 31-35.

20. Yumuk Z, Sayan M, Çalışkan Ş. Kronik hepatit C hastalarında oto-antikorların HCV RNA düzeyi ile ilişkisi. İnfeksiyon dergisi (Turkish journal of infection)2008; 22 (1):29-34.

21. Marazuela M, Garcia-Buey L, Gonzalez-Fernandez B, GarciaMonzon C, Arranz A,Borgue MJ, Moreno-Otero R. Thyroid autoimmune disorders in patients with chronic hepatitis $\mathrm{C}$ before and during interferon-D therapy. Clin Endocrinol 1996; 44 : 635-642.

22. Okanoue T, Sakomoto S, Yasui K, et al. Side effects of interferon on endocrine and respiratory system in 545 cases of choronic hepatitis. Japonese Gastroenterol 1994;91: 995-1002

23. Beşirbellioğlu AB, Görenek L, Gül HC, Hacıbektaşoğlu A. Hepatit C enfeksiyonlu hastalarda otoantikor seroprevalansı. Klinik Bilimler \& Doktor 1999; 5: 30-32.

24. Seçkin $Y$, Karıncaoğlu M, Cömert M, Ateş F, Yiğit iP, Yıldııım O, Toktaş H. Kronik hepatit $B$ ve $C$ hastalarında otoantikor görülme sıklığ. Cumhuriyet Tıp Derg 2009;31: 388-392. 